\title{
A mould-breaking cabinet? \\ Changes and continuities in the formation of the 2017 French government
}

\author{
Cristina Bucur \\ University of Oslo \\ cristina.bucur@stv.uio.no
}

\begin{abstract}
Emmanuel Macron's election as President of the Republic and the formation of a government that includes a mix of politicians from parties on the left and right of the political spectrum, as well as a significant share of non-partisan ministers, has been hailed by numerous commentators as an unprecedented overhaul of France's political life. This article examines how the two cabinets formed under prime minister Édouard Philippe in the shadow of the 2017 presidential and parliamentary elections compare to previous governments in the Fifth Republic. The analysis reveals a less than revolutionary break with previous patterns of government size, channels of ministerial recruitment, portfolio allocation, gender balance and ethnic diversity.
\end{abstract}




\section{The president and the prime minister appointment}

The Constitution of the Fifth Republic places the president at the centre of the government formation process. Article 8 grants the head of state unconstrained power to select the prime minister and to appoint all other cabinet members on his or her proposal. Thus, favourable circumstances, such as the support of a majority in parliament, allow the head of state to appoint a loyal and/or at least subordinate prime minister and take control over the government (Elgie 2013: 20). Several other constitutional provisions increase the president's authority over the executive decision-making process. For example, the right to chair cabinet meetings (under Article 9) allows the head of state to set the agenda and influence policy-making indirectly (Knapp and Wright 2006: 89). Article 5 grants the power to ensure the proper functioning of public authorities through arbitration to the head of state. This provision has been interpreted as a firm basis for the President's ability to keep a tight grip over state institutions (Carcassonne 2011: 55-6). In addition to the basis for presidential leadership provided by the Constitution, the direct election of the president ensures that the government's policy agenda is set by the president, while the legislative election following shortly after the presidential one is likely to provide the majority needed to pass the government's programme in parliament (Elgie 2013: 23). All these conditions for presidential pre-eminence were met in 2017, when Emmanuel Macron took office on the basis of a decisive victory in the presidential election, which was consolidated by the legislative election that granted his newly established party an overall majority in parliament. As a result, the new government and its policy programme were regarded as a direct expression of President Macron's political project.

Broadly speaking, French prime ministers taking office during periods of presidential dominance have been known to fall in two categories: those appointed at the beginning of the president's term, who are representative for the coalition that supported the president in the second election round; and those appointed mid-way through the presidential term, who are personally loyal to the president (Portelli 1997: 22). In general, prime ministerial appointments have been instrumental in widening the presidential majority and/or appeasing tensions in a divided coalition or presidential party. For example, President Pompidou's choice of ChabanDelmas as his prime minister in 1969 signalled the opening of the Gaullist party towards the centre-right (Portelli 1997: 22). Similarly, Michel Rocard was chosen by François Mitterrand in 1988 at the outset of his second term due to his ability to widen the narrow left-wing majority towards the centre (Knapp and Wright 2006: 81). In 1974, President Giscard d'Estaing appointed Jacques Chirac as his first prime minister instead of choosing a premier from his 
centrist UDF to acknowledge the role played by the Gaullist party in the presidential campaign. Under different circumstances, Jacques Chirac also started his second term in 2002 with a "gesture" to the middle ground, as he picked Jean-Pierre Raffarin as prime minister, although or precisely because he represented the centrist, non-Gaullist part of his newly formed Union for a Popular Movement (UMP) (Gaffney 2010: 178). To accommodate a fractious and rebellious UMP presidential party, Nicolas Sarkozy chose François Fillon as prime minister, who was a leading member of the party and had supported his presidential bid without being a long-time loyalist (Cole 2012: 317; Elgie 2013: 26). As opposed to his predecessors, François Hollande overlooked the balance of power in the highly factionalised Socialist Party (PS) when forming his first government in 2012. Jean-Marc Ayrault, a loyalist with no ministerial experience but who had been the president of the PS parliamentary group since 1997, was preferred as prime minister to the party leader Martine Aubry, who was the most experienced and popular choice as head of government (Murray 2013: 209). Moreover, President Hollande chose to populate the government with his supporters from the presidential primary instead of leaning on the majoritarian axis that had led the party since 2008 (Dolez 2015: 75). Ignoring the balance of power between the party factions proved to have far-reaching consequences for the working relationship between the executive and the presidential majority in parliament.

At first sight, one might be hard pressed to place Édouard Philippe, the mayor of Le Havre from the right-wing Les Républicains (LR) who took office in May 2017 as President Macron's first prime minister, either in the category of "rassembleurs" or in that of loyalists. A freshman in the National Assembly but with considerable experience as an elected official at different levels in local administration, Philippe was not a leading member of the LR party. He was, however, closely associated with Alain Juppé, whom he actively supported during the 2016 presidential primary of the centre-right. While Philippe refrained from endorsing Macron during the electoral campaign, which made him the first prime minister to take office under the Fifth Republic without actively supporting the incoming president, Juppé was unequivocal in his support for the candidate of the La République en Marche (LREM) ahead of the run-off. Two other members of the LR party were nominated in Philippe's government: Bruno Le Maire, a close collaborator of former prime minister Dominique de Villepin and agriculture minister under François Fillon, who went on to fight both Fillon and Nicolas Sarkozy for the presidency of the UMP party and the LR presidential nomination, was appointed as economy minister; and Gérald Darmanin, a rising star in the LR party close to Sarkozy, obtained the budget portfolio. As opposed to the PS, which was badly damaged during the presidential election and was bracing for a wipeout in the general election, the Republicans were still 
expected to return a significant group in the National Assembly. Thus, Macron's choice for Édouard Philippe as his first prime minister and the appointment of LR members associated with the main factions in the LR party reflected his own "gesture" intended to broaden political appeal and provide right-wing voters with sufficient incentives to support LREM candidates when it came to duels with the left or the extreme right.

\section{The cross-party government}

During the presidential campaign, Emmanuel Macron promised to appoint a fifteenmember government that would include politicians from the left, centre, and right, as well as non-political personalities (Coquaz 2017). To fit the bill, cabinet nominations from the rightwing LR were balanced by the appointment of two heavyweights from the Socialist Party: Gérard Collomb, a long-standing member of the Socialist Party, with extensive experience in both houses of parliament and a local official for over two decades, was appointed interior minister; while Jean-Yves Le Drian, who had held the defence portfolio in all cabinets formed under François Hollande's presidency, was promoted to foreign affairs. Philippe's first cabinet also included two members from the Radical Party of the Left (PRG), the traditional ally of the Socialists: Jacques Mézard, an experienced local official and member of the Senate since 2008, obtained the agriculture portfolio; while Anick Girardin, who had previously served in the Valls and Cazeneuve governments, acquired the overseas ministry. The pre-electoral coalition with the centrist MoDem party translated in the appointment of its leader, François Bayrou, as justice minister. His second in command in the party hierarchy, Marielle de Sarnez, was also appointed to cabinet as a delegated minister for European affairs.

Emmanuel Macron's La République en Marche (LREM) party was also represented in Édouard Philippe's first cabinet, although less prominently than it had usually been the case for the president's party during previous spells of presidential dominance. Only two LREM members joined the government as full ministers: Richard Ferrand, a long-standing member of the Socialist Party who had joined the En Marche! movement since its early take-off in April 2016 and served as its secretary general, was appointed minister for regions; while Sylvie Goulard, an MEP for MoDem since 2009 who had also joined LREM in 2016, was named as defence minister - the only woman in a high-profile post. Three other LREM representatives joined the government as secretaries of state: Christophe Castaner, who was Emmanuel Macron's spokesperson during the presidential campaign, became government spokesperson and also took charge over the executive's relations with parliament; Marlène Schiappa, a 
successful feminist blogger and deputy mayor for Mans, was given responsibility for gender equality (a similar role she had played in Emmanuel Macron's campaign team); and Mounir Mahjoubi, a 33-year old who contributed to François Hollande's presidential campaign and was a PS member before joining LREM in early 2017, took charge over digital economy.

Philippe's cabinet also seemed to carry out Emmanuel Macron's pledge of political renewal, as half of its members were drawn from the 'civil society' as experts in their respective fields. The most prominent of non-partisan appointments was that of Nicolas Hulot, the bestknown environmentalist in France, as minister of ecology and solidarity, a portfolio that also included full responsibility over transports and energy. Hulot, who had unsuccessfully competed for the Green Party's presidential nomination in 2012, had refused invitations to join the government from Jacques Chirac, Nicolas Sarkozy, and François Hollande, despite collaborating with all of them on environmental policies. For example, he worked as an advisor for François Hollande during the negotiations leading to the Paris climate agreement in 2015. Other non-partisan ministers obtained the health, culture, labour, education, research, and sports portfolios, as well as two junior minister posts related to transports and disability rights. Nevertheless, as most of the "civil society" representatives could be linked to the main political parties (Pommiers 2017), there were also doubts that a genuine break with the public policies conducted by previous right-wing and left-wing governments could be achieved (Bedock 2017), as well as fears that their opposed political views on key policies might be difficult to rein in by Emmanuel Macron and Édouard Philippe (Chapuis 2017).

As anticipated by the literature on presidential coattails (Shugart 1995; Amorim Neto and Cox 1997; Golder 2006; Elgie et al. 2014), the honeymoon legislative election held one month later confirmed the outcome of the presidential election and returned a solid majority for the newly elected president. LREM won 309 seats in the 577-seat National Assembly, an outright majority, while MoDem won 43 seats. The two parties decided to maintain their governing alliance, which technically made the government an oversized coalition. Moreover, the president kept the partnership with compatible factions from the LR and PS on board. However, allegations of nepotism concerning Richard Ferrand and the resignation of the two MoDem ministers and Sylvie Goulard because of accusations of misusing payments for assistants in the European Parliament triggered a cabinet reshuffle.

MoDem's François Bayrou and Marielle de Sarnez were replaced by Jacqueline Gourault, one of Bayrou's closest collaborators and a member in the party's national executive, as a delegated minister to the interior department, and Geneviève Darrieussecq, an experienced local official newly elected to the National Assembly, as a state secretary for the ministry of 
defence. LREM was compensated for the departure of Richard Ferrand and Sylvie Goulard by the appointment of Stéphane Travert, a former PS member who was elected as a LREM deputy in the June election, as minister of agriculture. Two of Emmanuel Macron's close collaborators also joined the government as state secretaries: Benjamin Griveaux, his campaign spokesperson, was tasked with shadowing the powerful LR-led ministry of economy and finance; while Julien Denormandie, Macron's former chief of staff at the economy ministry, was placed at the regions ministry led by the Radical Left party's Jacques Mézard (who was moved from the agriculture ministry to replace Richard Ferrand). Moreover, Brune Poirson, a newly-elected deputy under the LREM label, was assigned to the environment department.

The right-wing bloc was also reinforced by the appointment of Sébastien Lecornu, close to Bruno Le Maire, and Jean-Baptiste Lemoyne, a LR senator, as state secretaries. Moreover, Nathalie Loiseau, who had previously worked with Alain Juppé at the Foreign Affairs ministry, replaced Marielle de Sarnez as delegated minister for European affairs. Similarly, the cabinet's left-wing component was strengthened by the appointment of two "civil society" representatives linked to the Socialist Party to highly-ranked cabinet posts: Florence Parly, officially non-partisan but with significant ministerial experience in previous left-wing governments, replaced Sylvie Goulard as defence minister; Nicole Belloubet, a prominent local official and PS member until 2013 when she became a member of the Constitutional Council, replaced François Bayrou as justice minister. The two appointments were also seen as achieving a fairer distribution of powerful ministries among men and women. Thus, overall, the political balance of forces in Édouard Philippe's government was not significantly altered by the June reshuffle, as the left, right and centre maintained their representatives in government and the portfolios they had been allocated in Édouard Philippe's initial cabinet.

\section{Government size and ministerial hierarchy}

As already mentioned, during the presidential campaign Emmanuel Macron pledged to form a "restrained" government that would include fifteen members at most. How unusual are smallsized cabinets compared to standard patterns of government formation in France? In general, the size and composition of governments in the Fifth Republic has varied considerably from one cabinet to another. Much of this complexity is generated by the existence of different classes of ministers (Duhamel 2011: 622). The ministerial hierarchy is laid out in a presidential decree that accompanies the appointment of each new government. Apart from the "Premier ministre" and ordinary "Ministres" responsible for a clearly delimited portfolio, cabinets may 
include "Ministres d'État", the highest rank reserved for senior politicians, and "Ministres délégués". The latter are responsible for specific domains within larger portfolios under the authority of the prime minister or other cabinet members. Minister of state titles are often granted to senior politicians from coalition partners, to acknowledge their party's involvement in the core executive decision-making. However, the only concrete power conferred to state ministers is the ability to organise inter-ministerial meetings, just like the prime minister. The extended government structure may also include "Secrétaires d'Etat" (and a High commissioner under Nicolas Sarkozy's presidency), who have considerably less power than full ministers. State secretaries do not have their own budget, cannot sign decrees, and may attend cabinet meetings only when topics related to their jurisdiction are on the agenda (Delrue and Vaudano 2017). As a result, these positions are more likely to be allocated to middle-rank politicians, independents, and women.

By and large, the unwritten rules regarding the distribution of ministerial ranks seem to have been followed in Édouard Philippe's first government, which included three state ministers: Gérard Collomb, the most senior representative of the left; François Bayrou, the leader of the centrist MoDem; and Nicolas Hulot, as the representative of the 'civil society'. In this way, one representative of the right, left, centre, and 'civil society' received a front-row place in the cabinet (though none of these positions were occupied by women). As in the past, the minister of state rank singled out the political heavyweights in cabinet. Not any member of a political party can obtain it and its attachment to a cabinet portfolio indicates the political weight of the seat-holder first and only second the prominence of a policy area. Thus, when François Bayrou stepped down, the minister of state title was not automatically conferred to one of the other MoDem representatives in government. Nor was the minister of state rank granted to Nicole Belloubet, who succeeded François Bayrou as justice minister, although the portfolio retained its third place in the ministerial hierarchy. For the same reason, none of the LREM ministers acquired the minister of state rank. The remaining ministerial portfolios went to other cabinet members formerly associated with the main parties of the right and left, while most delegated ministers and state secretaries positions were occupied by LREM supporters, non-partisan figures and women.

To obtain a clearer image of how the two cabinets formed under Édouard Philippe compare with their predecessors, Figure 1 presents descriptive statistics about the size and types of ministers appointed to all governments that formally took office between 1959 and 2017 . The average government size is 33.6 (prime ministers were not included in this count). This 
benchmark is indicated by the vertical orange line, so that each government can be easily compared to the general average.

[Figure 1]

As Figure 1 indicates, small governments have not been unheard of during the Fifth Republic. Nor are they a recent phenomenon. For example, the size of governments formed under de Gaulle's presidency was well under the general average of 33.6 ministers. Édouard Balladur and Lionel Jospin, both prime ministers taking office during periods of cohabitation, headed relatively small cabinets as well. The record for the most restrained government belongs to François Fillon, whose first cabinet counted only 20 members. Thus, with 19 cabinet members (including the prime minister) and four state secretaries, Édouard Philippe's first government was slightly larger than the 15-person government promised by Emmanuel Macron during the electoral campaign, but well under the average government size. Similar to François Fillon, who added 11 more secretaries of state to his government after the legislative election, Édouard Philippe's second government increased to 30 members after the general election, drawing closer to the general average.

As can be seen in Figure 1, the number of delegated ministers and state secretaries account for most of the variation in the size of governments. At times, they may also be removed from the cabinet altogether. For example, while Jean-Marc Ayrault chose not to appoint any state secretaries, his successors, Manuel Valls and Bernard Cazeneuve, preferred to do without delegated ministers. However, each of them more than compensated for the absence of either ministerial rank by appointing more of the other - PM Ayrault nominated a record-breaking number of 18 delegated ministers in his second government, while PM Valls and PM Cazeneuve appointed between 14 and 20 state secretaries. In contrast, all three prime ministers appointed a similar number of full ministers (between 16 and 20). To give another example, François Fillon also did without delegated ministers in his second (and first) cabinet, which counted 15 state secretaries. Interestingly, however, although his third cabinet included the same number of full ministers and the same number of appointments below the full ministerial rank, seven of them were promoted as delegated ministers. Similarly, while Édouard Philippe kept the same number of full ministers in his second cabinet, he appointed no less than seven delegated ministers and state secretaries without portfolio, who are meant to support their designated ministers without having been assigned a specific jurisdiction (Le Monde 2017). 
The bottom line regarding the hierarchy of ministerial posts is that appointments at delegated ministers or state secretary level, which do not exert full control over a ministerial portfolio, are one way to foster efficiency in the ministerial councils by reducing the number of full ministers and increasing the number of lower-ranked appointments that are designed to provide specialised support to senior ministers. These appointments may also be used by presidents or prime ministers as gifts of patronage offering fast-track promotion to governmentlevel to loyal middle-level party members or political outsiders, like independents or women, that can be also easily withdrawn (Murray 2013: 208). Thus, to understand the distribution of key posts in the government, it might be more useful to focus on the size of the core executive. In fact, the average number of full ministers across all governments is 17.6 , almost half than that including delegated ministers and state secretaries. As the vertical green line in Figure 1 indicates, there is much less variation across governments when it comes to the number of full ministers. From this perspective, the two cabinets formed under Édouard Philippe's cabinets are much closer to the norm.

\section{Portfolio allocation and ministerial importance}

One way to evaluate how governing partners divided cabinet payoffs is by comparing the relationship between the amount of resources they contribute to the ruling coalition and the share of cabinet seats they receive in exchange (Gamson 1961: 376). Although political scientists expect formateur parties (i.e. the ones that get to move first in the game of government formation) to secure more than their fair share of cabinet posts (Baron and Ferejohn 1989; Ansolabehere et al. 2005), empirical studies find that the proportion of ministries each coalition member receives is nearly proportional to the legislative seats it contributes to the government coalition (Warwick and Druckman 2006). The Fifth Republic is actually one of the few cases where the proportionality relationship holds in its strict interpretation, in that the linkage of seat shares and portfolio shares comes closes to the one-to-one hypothesised relationship than in any other country in Western Europe (Bucur 2016). However, linking legislative seat share and portfolio shares would make little sense this time around given the synthesis of the left, right, and centre carried out by Emmanuel Macron, who put together an executive team dominated by non-political cabinet members. Nevertheless, since not all cabinet posts carry the same weight, one can compare the size of the ministerial prize seized by each bloc by considering the importance of each portfolio. 
Previous research has constructed cross-national measures of portfolio importance using expert measurements of portfolio salience (Druckman and Warwick 2005; Druckman and Roberts 2008). A country-specific measure of portfolio importance in the Fifth French Republic has also been developed based on the ordres protocolaires that accompany the appointment of each new government and list cabinet members and their jurisdictions in hierarchical order (Bucur 2016). As the rankings record changes from one cabinet to another, such as ministerial promotions, demotions, and sideways moves, these context-sensitive sources also capture variation in the importance of portfolios from one government to another. As a result, a party's share of the ministerial prize can be re-estimated in each government or after a major cabinet reshuffle. Thus, as opposed to the expert survey estimates, the ministerial rankings can be used to determine salience scores for single posts in each government, as well as mean estimates for the entire period of time a given portfolio appeared in government. This measure can also be used to assess the distribution of ministerial importance to the political blocs represented in Emmanuel Macron's government.

The following steps were taken to estimate the importance of portfolios included in the two cabinets formed in the shadow of the 2017 presidential and parliamentary elections. Following the procedure employed by Bucur (2016), ordinal rankings were transformed into interval scores using an exponential function that halves the importance of portfolio half-way through the pecking order. A party's salience-weighted portfolio share was computed as the normalized sum of the average salience scores of all its portfolios (all salience values were normalized to ensure that they add up to 1 in each government). The distribution of ministerial importance between the representatives of the main blocs in the two cabinets (LREM, MoDem, LR, PS, PRG, and Independents) is indicated by the boxplots in Figure 2. Only full cabinet positions were included in this analysis (i.e. full ministers and delegated ministers).

[Figure 2]

By and large, the data in Figure 2 confirms most commentators' views on the distribution of important portfolios to the main parties of the left and right. Thus, although independent ministers held half of the posts in Édouard Philippe's initial cabinet (left-hand panel in Figure 2), their importance was generally lower than that of portfolios allocated to political representatives. In fact, apart from Nicolas Hulot's portfolio, which was ranked $3^{\text {rd }}$ on the ministerial ladder, the posts with jurisdiction over social policies held by independent ministers were placed in the second half of the ranking. From this point of view, the distribution 
of portfolios confirmed old patterns which saw ministers advancing to cabinet through political channels obtaining more important posts that those coming to cabinet from the civil service (Gaxie 1986: 68-9). In contrast, although only two PS members joined the government, the ranking of the two key portfolios they were allocated as $2^{\text {nd }}$ (i.e. interior) and $6^{\text {th }}$ (i.e. foreign affairs) in the 19-seat cabinet meant their ministerial prize was more valuable in absolute terms than that of any other party. By comparison, the Left Radicals were also allocated two portfolios, but their ranking on the $13^{\text {th }}$ (i.e. agriculture) and $16^{\text {th }}$ (i.e. overseas) places lowered the overall prize value. Similarly, the allocation of the prime ministership to the right-wing LR was balanced by the placement of their other two cabinet posts on the $10^{\text {th }}$ (i.e. economy) and $14^{\text {th }}$ (i.e. budget) ranking positions. With two ministries each, the formal coalition parties, LREM and MoDem, were not particularly advantaged in portfolio allocation. The latter's allocation of a state ministry was balanced by the placement of its second post on the last ministerial position. The significant gap between the salience of the two portfolios stands out in Figure 2 as well (left-hand panel). By comparison, LREM obtained two posts placed in the upper half of the ministerial ladder (i.e. defence and regions, ranked $5^{\text {th }}$ and $7^{\text {th }}$ respectively).

Although the cabinet formed after the legislative election did not alter significantly the political equilibrium, the data in the right-hand panel in Figure 2 suggests some adjustments in the distribution of ministerial importance. The parties having the most to lose from the June reshuffle were LREM and MoDem, as their ministers left the government amid corruption allegations. Both parties made only one appointment to the cabinet. LREM exchanged the defence and regions ministries (ranked $5^{\text {th }}$ and $7^{\text {th }}$ ) with the agriculture post (ranked $13^{\text {th }}$ ). However, due to the increase in the number of state secretaries in the second cabinet, LREM improved its share of government seats to almost one quarter, holding one full ministry and six state secretaries out of the extended cabinet's thirty posts. That was still considerably less than the share of cabinet portfolios a formateur party with an absolute majority in parliament would be expected to keep for itself.

While MoDem remained an unambiguous part of the presidential majority, the party lost its central position in the core executive. François Bayrou and Marielle de Sarnez were not replaced by other MoDem representatives at the justice ministry and the state secretariat for European affairs the party had held in Édouard Philippe's initial cabinet. Nor was the party compensated with another full ministry. Instead, a delegated minister and a state secretary were assigned to the interior and defence ministries. Thus, rather than claiming separate portfolios that might have been of lesser importance, MoDem seems to have opted for shadowing two of the most salient ministries in Philippe's second cabinet. 
The independent bloc seems to have benefitted the most from the cabinet reshuffle. The share of portfolios reaped by non-partisan ministers increased, as did their importance, as François Bayrou (MoDem) and Richard Ferrand (LREM) were replaced by formally nonpartisan Nicole Belloubet (justice ministry, ranked $4^{\text {th }}$ ) and Florence Parly (defence ministry, ranked $\left.6^{\text {th }}\right)$. Interestingly, though, this time around Nicolas Hulot's state ministry was shadowed by state secretaries from the right (Jean-Baptiste Lemoyne), left (Élisabeth Borne), and centre (Brune Poirson). The left not only retained their two key portfolios, but Jean-Yves Le Drian (foreign affairs) was also promoted from the $6^{\text {th }}$ to the $5^{\text {th }}$ position. The salience of positions held by PRG ministers also improved, as Jacques Mézard replaced Richard Ferrand at the regions portfolio (ranked $7^{\text {th }}$ ). The LR grip on economic ministries remained unchanged, as did their position in the formal ranking. However, a LREM state secretary was appointed to shadow the economy minister, indicating the president's determination to keep economic policies under control (Courtois 2017; Royer and Pietralunga 2017).

\section{Ministerial selection and political experience}

The two governments formed under Édouard Philippe gave the impression of a breach with previous patterns of ministerial recruitment because they brought together representatives of different political families of the left and right, while also giving considerable room to unelected individuals and experts unknown to the public. However, a more attentive look reveals that the mix of politicians appointed had long elective careers at both national and local levels. Similarly, many of the politically non-affiliated members of the cabinet had followed senior civil service career paths and had considerable experience as advisers in ministerial cabinets. Figure 3 presents the distribution of different types of political experience across the two cabinets, differentiating between the positions that the new ministers occupied just before their appointment to cabinet and prior experience.

\section{[Figure 3]}

As Article 23 in the Constitution of the Fifth Republic makes cabinet and parliamentary office incompatible, ministers can be recruited from outside the parliamentary pool. Despite the removal of this barrier to ministerial office, though, between 60 and $75 \%$ of French ministers have arrived in government through the parliamentary channel (Kam and Indridason 2009: 47). At first sight, Édouard Philippe's government seems to be well beyond 
this threshold, as only $40 \%$ of the initial cabinet members were recruited from among incumbent deputies, senators, or members of the European Parliament (MEPs). A few other ministers had also served in parliament at some point during their careers. However, there was significant variation in the level of experience. For example, Gérard Collomb had been a senator for almost twenty years, after having served as a deputy for almost a decade under François Mitterrand first presidential term. Jean-Yves Le Drian and François Bayrou could also claim parliamentary careers spanning several decades. The cabinet also included experienced MEPs, like Sylvie Goulard and Marielle de Sarnez, sending a clear message about Emmanuel Macron's commitment to deeper European co-operation and integration. Others cabinet members were less experienced parliamentarians. For example, like PM Philippe, Richard Ferrand, and Christophe Castaner, were just completing their first full term as members of the National Assembly. The number of parliamentarians increased in the second Philippe cabinet, as several of the newly appointed ministers and incoming state secretaries were successfully elected as LREM deputies in the 2017 election.

By and large, while there is no denying that fewer members in the new government were drawn from the parliamentary pool than before, it might be too early to conclude that a "de-parliamentarisation" of ministerial careers (Costa and Kerrouche 2009) is underway. Nor is a low number of non-parliamentary ministers entirely unprecedented. For example, due to Nicolas Sarkozy's “ouverture” policy, only half of the ministers in François Fillon's first cabinet had been recruited from parliament. It would be interesting to see if the next reshuffles and enlargements of the cabinet will confirm the tendency to select ministers from outside the parliament.

The new ministers do not seem to completely lack cabinet experience either. According to the data in Figure 2, at least one third of the ministers in both cabinets had either held a ministerial portfolio in the past or had experience as cabinet advisers. Two ministers were recruited from Manuel Valls's government. Experienced Socialist Jean-Yves Le Drian was promoted from the defence to foreign affairs ministry, while Radical Left's Anick Girardin exchanged the civil service ministry for the overseas department. Other cabinet members had held a full ministerial portfolio in the past, such as François Bayrou, who had served as education minister in the right-wing government led by Édouard Balladur and Alain Juppé, and Bruno Le Maire, who was agriculture minister in François Fillon's government. Other ministers, including the non-politically affiliated ones, were experienced ministerial advisors. For example, Jean-Michel Blanquer, formally an independent minister, had been closely associated with the elaboration of education policies under right-wing governments and had 
served as deputy director in the cabinet of Education minister Gilles de Robien in Dominique de Villepin's government (Bedock 2017). Similarly, while Muriel Pénicaud and Elisabeth Borne in Édouard Philippe's initial cabinet, as well as Florence Parly and Nathalie Loiseau in the reshuffled cabinet, were renown experts in their respective fields, they had also been involved in ministerial cabinets in the past.

A relatively high number of ministers arrived in the two governments with experience in local politics. More than half of the new cabinet members were local elected officials, some of them having executive responsibilities such as mayors (Édouard Philippe, Gérard Collomb, François Bayrou, Gérald Darmanin, Christophe Castaner, Geneviève Darrieussecq) or presidents of regional councils (Gérald Darmanin and Jean-Yves Le Drian). Other cabinet members held positions as councillors at municipal (Jacques Mézard, Marlène Schiappa), departmental (Marielle de Sarnez), regional (Richard Ferrand, Stéphane Travert), or territorial (Anick Girardin) level. The local politics career path to ministerial office is not unusual in French politics. In fact, the accumulation of local and national mandates, known as the cumul des mandats, is regarded as the defining feature of French politicians (Dewoghélaëre et al. 2006; Mény 2008). As most deputies and senators hold at least one local mandate and the parliament is often the main selection pool for the government, it is quite common for French ministers to hold multiple mandates. Moreover, counting on a local stronghold as a mayor or president of departmental or regional council not only increases one's chances of being appointed to government, but is also known to strengthen their position in the cabinet (François 2006; Bach 2012).

While several attempts have been made to limit the cumul practice among deputies and senators by law, mostly unsuccessful, no systematic rules have been adopted to prevent ministers from simultaneously holding a local office. For example, while Lionel Jospin conditioned the appointment of his cabinet ministers in 1997 on giving up of local executive offices, exceptions were made for high-profile ministers who ran in the 2001 municipal election. Ministers serving in François Fillon's government had the opposite experience with the non-cumul rule. While holding multiple office was initially allowed, a non-cumul rule of cabinet and local offices was announced ahead of the 2010 regional election (Bucur 2013). François Hollande also pledged to forbid ministers to hold a local mandate of any kind. Most cabinet members in the Ayrault and Valls governments complied with this requirement, but exceptions, such as Jean-Yves Le Drian, were occasionally tolerated. More recently, Emmanuel Macron followed up on his electoral pledge to impose a non-cumul rule by asking ministers holding an executive local office to choose between the cabinet seat and local responsibilities. 
A legal ban on the accumulation of offices for ministers has also been included in the draft bill for the "moralisation of public life" presented by François Bayrou in the Council of Ministers shortly before he stepped down as justice minister.

Unsurprisingly, given Emmanuel Macron's political renewal pledge, few of the new ministers held high positions in the party hierarchy. Nevertheless, this was the case for François Bayrou, the leader of MoDem, while Marielle de Sarnez and Jacqueline Gourault acted as vicepresidents of the party. Anick Girardin was also one of the Left Radical Party's vice presidents, while Richard Ferrand acted as the secretary general of LREM. In the more distant or recent past, Gérard Collomb, Gérald Darmanin, and currently non-partisan Florence Parly had also held leadership positions in their parties of origin (PS for Collomb and Parly, LR for Darmanin). The near absence of political heavyweights from government separates Édouard Philippe's cabinet from its predecessors, as the importance of political militantism as a channel for ministerial appointments had gradually increased since the early days of the Fifth Republic. For example, the proportion of national party elites appointed to cabinets almost tripled from 1958 until the mid-1980s, and reached a peak of $77 \%$ under Mitterrand's first presidential term (Gaxie 1986: 64). Similarly, the cabinets formed under Lionel Jospin and François Fillon were dominated by incumbent or former party executives.

Overall, the composition of the new government displayed a mixed picture in terms of political experience. While experienced politicians make up a smaller group than before, a nonnegligible number of cabinet members followed the conventional career path to executive office, which normally starts at local level and involves winning a general election before advancing to the cabinet. Moreover, the fact that both cabinets have boasted a greater share of non-partisan members than before could hardly hide that fact many of them were no strangers to politics. According to Le Monde, only five of the 23 members in Philippe's initial cabinet had not worked with political parties before (Pommiers 2017).

\section{Gender balance and ethnic diversity}

In spite of appointing a parity cabinet, President Macron's early delivery on his gender parity pledge was seen as disappointing (Dupont 2017). At first sight, this reaction might seem surprising, given that half of the new ministers appointed in the two cabinets were women (discounting the male prime minister). However, although it might be too early to say that parity governments have become the norm in French politics, a high number of women ministers no longer impresses. For a comparative overview, Figure 4 presents the percentage of women 
ministers appointed in all French governments during the Fifth Republic, which includes both full cabinet posts and secretaries of state positions. As this data indicates, the appointment of women ministers remained rather exceptional until the 1990s. In fact, the first woman to be appointed as a full minister was Simone Veil, who took office as health minister in Jacques Chirac's 1974 cabinet. The situation remained largely unchanged until Édith Cresson was appointed prime minister briefly during 1991-1992. After the mid-1990s, though, the appointment of women to government increased significantly and has generally surpassed the representation of women in parliament (Murray 2013, 2016). Thus, while Emmanuel Macron's parity cabinet stands out in comparison with the average French government, it seems to be following closely the trend started by Nicolas Sarkozy and François Hollande, who also vowed to ensure gender parity in their governments.

[Figure 4]

Since 1995, when Alain Juppé nominated women for almost a third of the available positions in his government but failed to give them real power to influence executive decisionmaking (Sineau 2011: 167), attention has shifted to the importance of ministries allocated to women. Thus, Nicolas Sarkozy's initial cabinet was praised not only because it included a record number of women, seven out of a cabinet of 15 , but also because they were given highranking positions, including the interior and justice ministries. Nevertheless, in the post-election expansion of the government and then throughout Nicolas Sarkozy's term, the number of women ministers declined to a third of the government and many of the initial high-profile figures gradually disappeared from public view (Murray 2009: 32). François Hollande also delivered on his commitment to have an equal number of women and men in government. However, he was criticised for appointing relatively junior women to cabinet and for allocating them considerably less powerful ministries (Murray 2013: 209). Therefore, Emmanuel Macron's government was bound to be scrutinised according to the same criteria: the profile of the women appointed in cabinet and the importance of their portfolios.

Édouard Philippe's initial government, contained nine women ministers out of a cabinet of 19 and 11 out of the wider government composition of 23 members. The almost equal distribution of women and men in cabinet was eclipsed by the unequal distribution of power. All top portfolios, including the prime minister, the three minister of state positions, the environment, justice, interior, foreign affairs, and finance ministries went to men. Women obtained the usual low-profile stereotypical portfolios associated with caring roles, such as 
health, labour, culture, disabilities, and sports. The most senior woman in a non-stereotypical post was Sylvie Goulard, who obtained the defence portfolio. The absence of a women's ministry promised by Emmanuel Macron during the presidential campaign was another disappointment. Instead of a full ministry, as it had been under François Hollande's presidency, the new government included only a state secretariat. Its placement on the $20^{\text {th }}$ position in the ministerial hierarchy was qualified by the French Collective for Women's Rights (CNDF) as humiliating (Dupont 2017). Moreover, while the male ministers had been active in political parties, most women except for Sylvie Goulard (LREM), Marielle de Sarnez (MoDem) and Anick Girardin (PRG) were drawn from outside party politics. As a result, while male ministers had some previous ministerial experience, most women except for Anick Girardin had at most acted as advisers in ministerial cabinets. On the other hand, the fact that all women ministers were senior public servants and renowned experts in the fields, made them less susceptible to criticism from male rivals and to the vulnerability associated with the traditional "fait du prince" (Murray 2009: 33).

Following the post-election expansion of the government to 30 members, 15 of whom were women, a fairer distribution of portfolios was achieved, as the justice ministry passed from François Bayrou to Nicole Belloubet. Nevertheless, as most of the other portfolios did not change hands and the new cabinet members who joined the government were state secretaries, the balance of power between male and female ministers did not change significantly. One can also use the measure of portfolio importance introduced above to determine a more precise distribution of ministerial importance between male and female ministers. Previous research has found that, on average, the ministries received by women in Jean-Marc Ayrault's first cabinet were half as important as the those allocated to men (Little 2012). The same conclusion can be drawn from the boxplots presented in Figure 5, which illustrate the distribution of ministerial importance between male and female ministers in the two cabinets formed by Édouard Philippe. As in the previous analysis, only full cabinet positions were included in this analysis (i.e. full ministers and delegated ministers). The importance of ministries is assessed based on their position in the ordre protocolaire. The lower importance of portfolios allocated to women is explained by the fact that only the defence ministry was placed in the top half of the ranking initially, followed by the justice department in the post-election cabinet. In both cabinets, women dominated the bottom half of the ministerial hierarchy. If the measure of portfolio importance used mean estimates for the entire period of time a portfolio appeared in government during the Fifth Republic instead of focusing on the ministerial rankings in the last 
two cabinets, then the gap between the importance of ministries allocated to men and women in the last two governments is reduced, but male ministers are still favoured.

\section{[Figure 5]}

As far as the ethnic diversity is concerned, the new government did not come on top of its predecessors. If anything, it seemed to move away from the increasing representation trends set under the presidencies of Nicolas Sarkozy and François Hollande. Since the early 2000s, ethnic minorities, which are estimated to make up about $15 \%$ of the mainland population in France, had been much better represented in government than in parliament (Murray 2016: 592). For example, the proportion of minority ministers in all governments under François Hollande's presidency was around 20\% (Motet 2017), while ethnic minority deputies held only $1.8 \%$ of the seats in the National Assembly (Murray 2016: 593). In the 2017 legislature the number of ethnic minority deputies increased to $6.4 \%$ of seats (Couvelaire 2017), but Édouard Philippe's government comprises only full minister and one state secretary. The former is Laura Flessel, the Guadeloupe-born Olympic fencing champion who took office as minister of sports (and was placed on the last position in the hierarchy of full ministries), while the latter is Mounir Mahjoubi, a French national of Moroccan origin who is responsible for digital economy (he also occupied the last position among junior ministers in Philippe's initial cabinet). Thus, given the post-election extension of the cabinet to 30 members, the proportion of ethnic minorities is equal in the government and parliament. The minority ministers' position in the government hierarchy and their restrained jurisdictions might also suggest their relative marginalisation in the executive decision-making process. On the other hand, a high number of minority ministers does not guarantee a significant impact on substantive policy outcomes. Previous research has shown that minority ministers appointed to French cabinets, a vast majority of whom had been women, have had a mixed record of policy influence due to their short tenures and clashes of personality and political ideology (Murray 2016; Garrett 2017). It will be interesting to see if minority diversity appointments to cabinet will have a stronger impact on policy-making under the new presidency, giving rise to minority-specific policies, and if they will come at the expense of symbolic appointments to cabinet of ethnic minority women.

\section{Conclusion}


Did Emmanuel Macron's new cabinet break with previous patterns of ministerial appointments in France or was it business as usual in government formation? The answer is somewhere in the middle. On the one hand, the formation of a cross-party cabinet was associated with a higher degree of change than Nicolas Sarkozy's 2007 "ouverture" policy, which had resulted in the appointment to government of several politicians associated with the centre-left parties, such as Hervé Morin and Bernard Kouchner. The composition of François Fillon's cabinet was perceived as a strategic move to split the opposition and oppose arguments that voters should opt for a left-leaning legislature to balance Nicolas Sarkozy's right-wing agenda (Kam and Indridason 2009: 47). In contrast, rather than merely opening the government to one political side, Emmanuel Macron was praised for achieving a genuine synthesis of the centre, centreright, and centre-left in government and promoting the renewal of political class through the inclusion of a non-negligible share of non-partisan experts in government (Chapuis 2017). That said, it remains to be seen how long independent ministers, who lack their own power bases and depend on Emmanuel Macron for their positions, will last in office and if they will start disappearing from public view in the next cabinet reshuffles.

On the other hand, the new government did not really break with previous patterns of ministerial selection and portfolio allocation. Ministers drawn from the main political parties obtained the most important portfolios, while non-partisan members were given responsibilities over lower profiles policy areas. With the notable exception of the defence and justice portfolios, women and representatives of ethnic minorities received less powerful ministries as well. The composition of the new government also displayed a mixed picture in terms of political experience. While experienced politicians made up a smaller group than before, a nonnegligible number of cabinet members had followed conventional career paths, coming to government as parliamentarians, mayors, party executives, or cabinet advisers. Ultimately, though, it remains to be seen whether ministers with opposing political views will ensure the continuity of previous policies or whether they will be able to carry out Emmanuel Macron's project of political change. 


\section{List of Figures}

Figure 1. Comparative overview of government size in the Fifth Republic

\section{Cabinet size and ministerial ranks in French governments}

(1959-2017)

2017 Philippe 2

2016 Cazeneuve

2014 Valls 2

2014 Valls 1

2012 Ayrault 2

2012 Ayrault 1

2010 Fillon 3

2007 Fillon 2

2007 Fillon 1

2005 de Villepin

2004 Raffarin 3

2002 Raffarin 2

2002 Raffarin 1

1997 Jospin

1995 Juppé 2

1995 Juppé 1

1993 Balladur

1992 Bérégovoy

1991 Cresson

1988 Rocard 2

1988 Rocard 1

1986 Chirac 2

1984 Fabius

1983 Mauroy 3

1981 Mauroy 2

1981 Mauroy 1

1978 Barre 3

1977 Barre 2

1976 Barre 1

1974 Chirac 1

1974 Messmer 2

1973 Messmer 2

1972 Messmer 1

1969 Chaban-Delmas

1968 Couve de Murville

1967 Pompidou 4

1966 Pompidou 3

1962 Pompidou 2

1962 Pompidou 1

1959 Debré
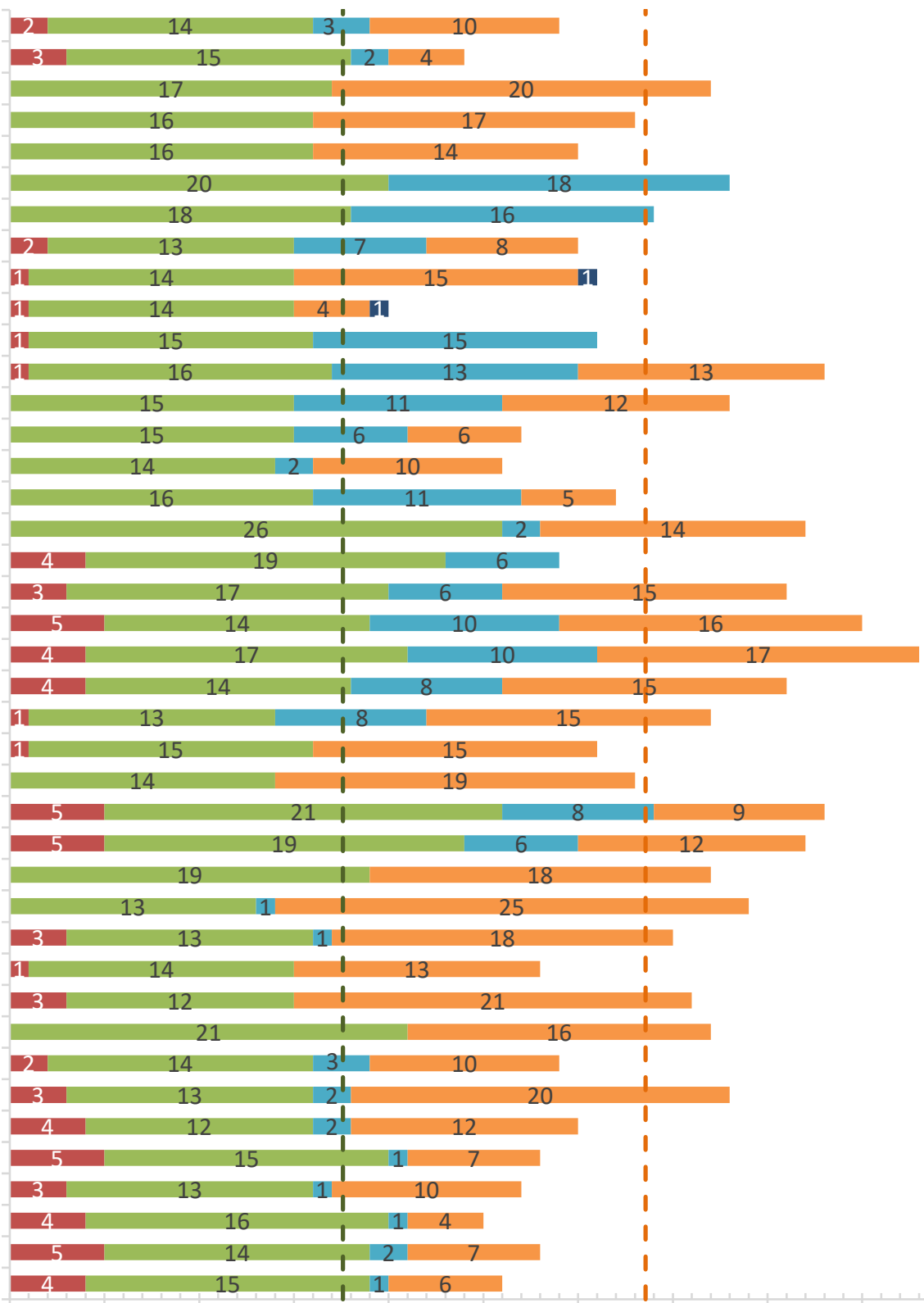

0

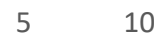

15

20

30

35

40

State Ministers

Delegated Ministers

Ministers

High Commissioner

State secretaries

_ - - Average number of full ministers

Note: Prime Ministers not included. Only the initial membership of each cabinet is considered.

Source: Cabinet membership data collected from the Journal Officiel de la République Française. 
Figure 2. The distribution of ministerial importance according to political affiliation
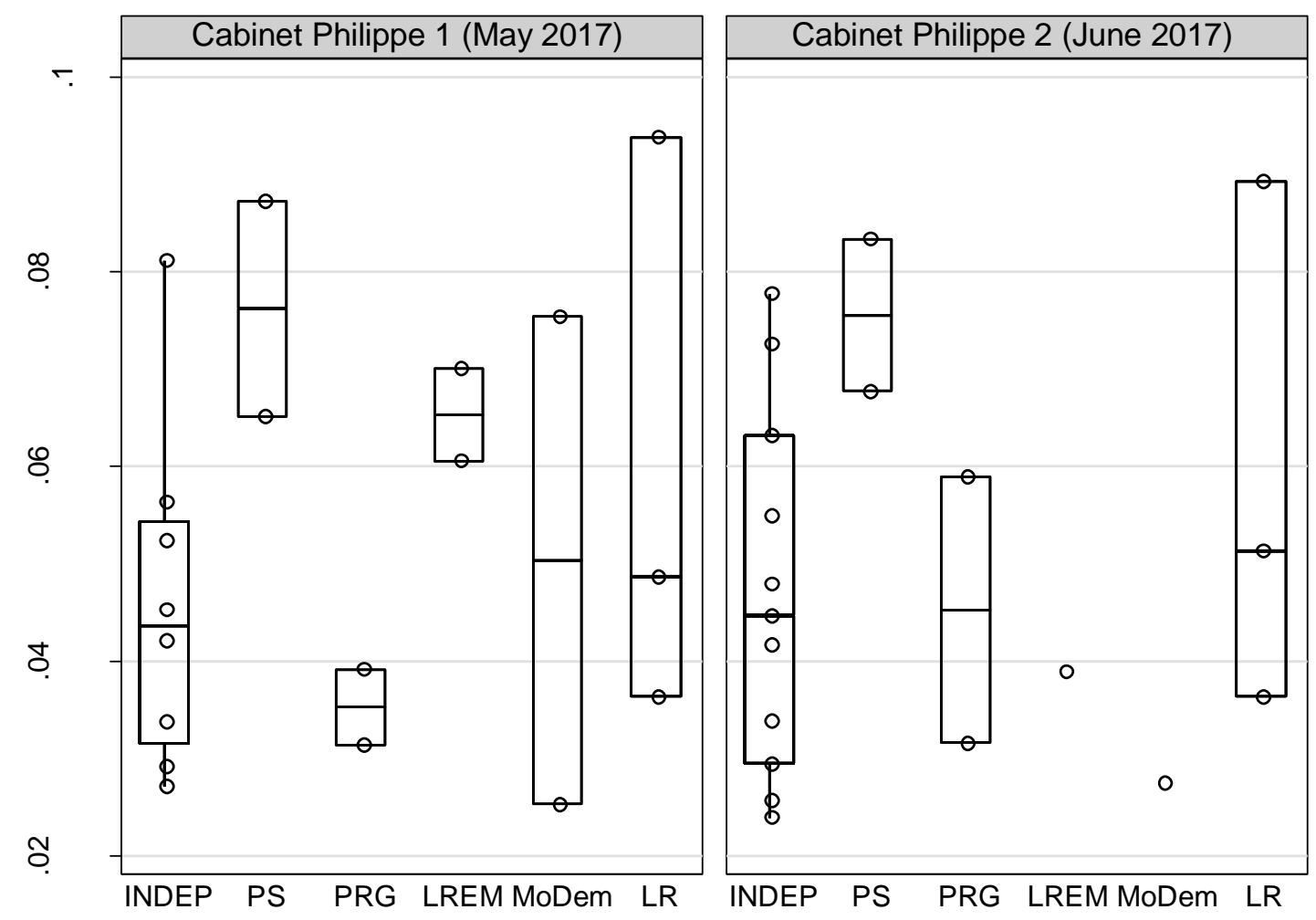

Note: State secretaries not included. 
Figure 3. Channels of ministerial recruitment

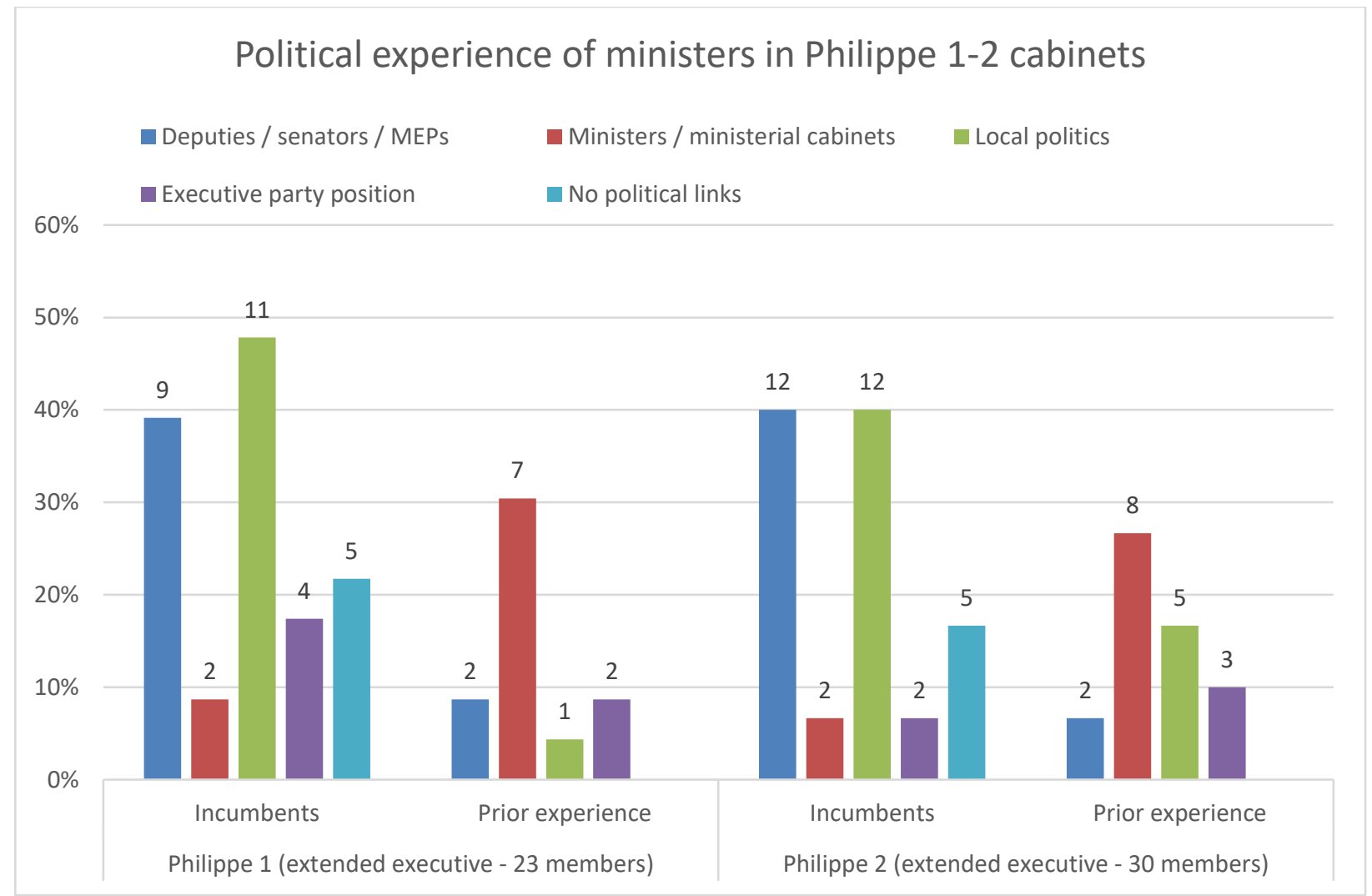

Note: Prime minister and state secretaries included. 
Figure 4. Comparative overview of women ministers in French governments

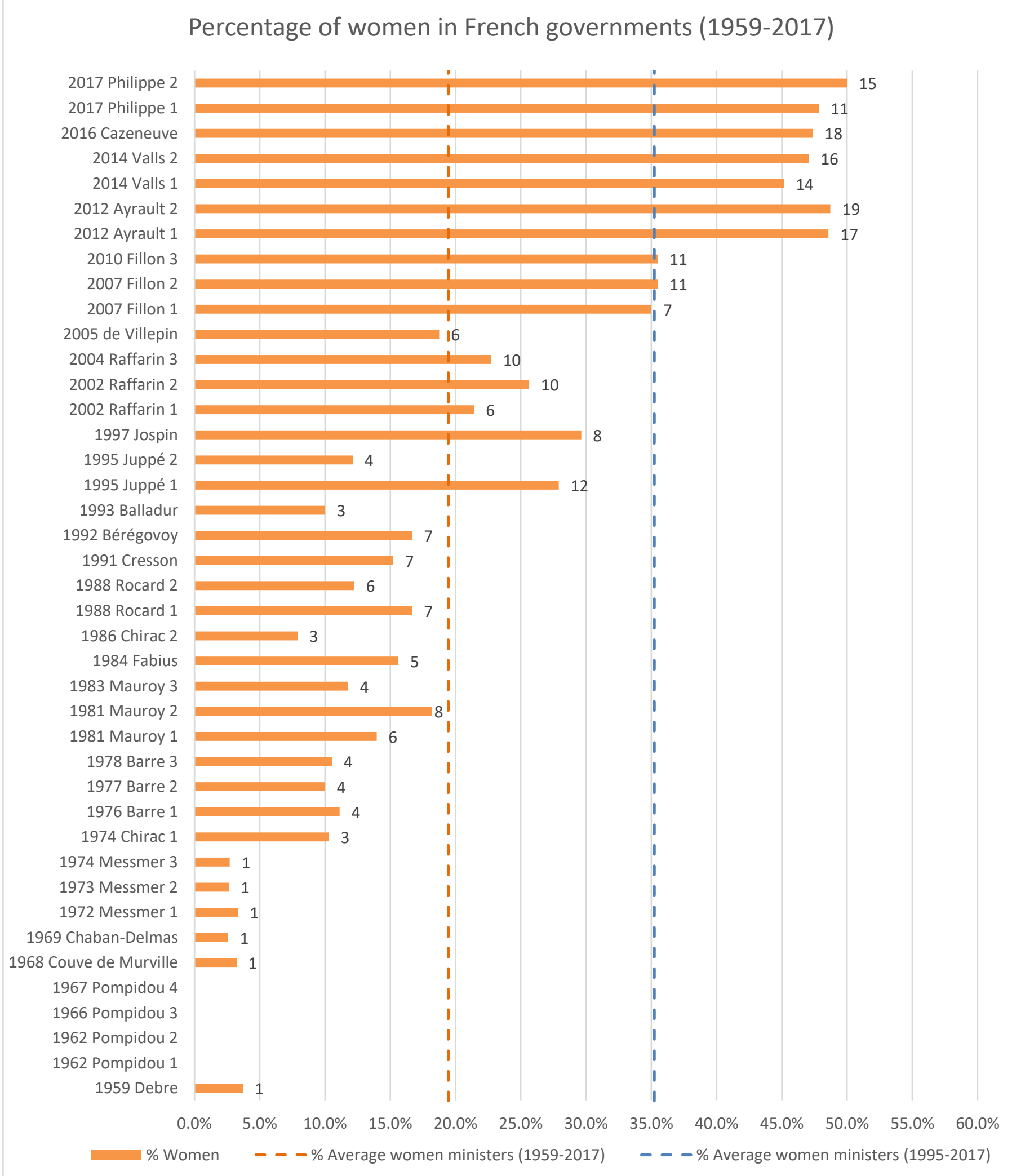

Note: Prime ministers and state secretaries included. Only initial members in each cabinet are counted. Source: Cabinet membership data collected from the Journal Officiel de la République Française. 
Figure 5. The distribution of portfolio importance between male and female ministers
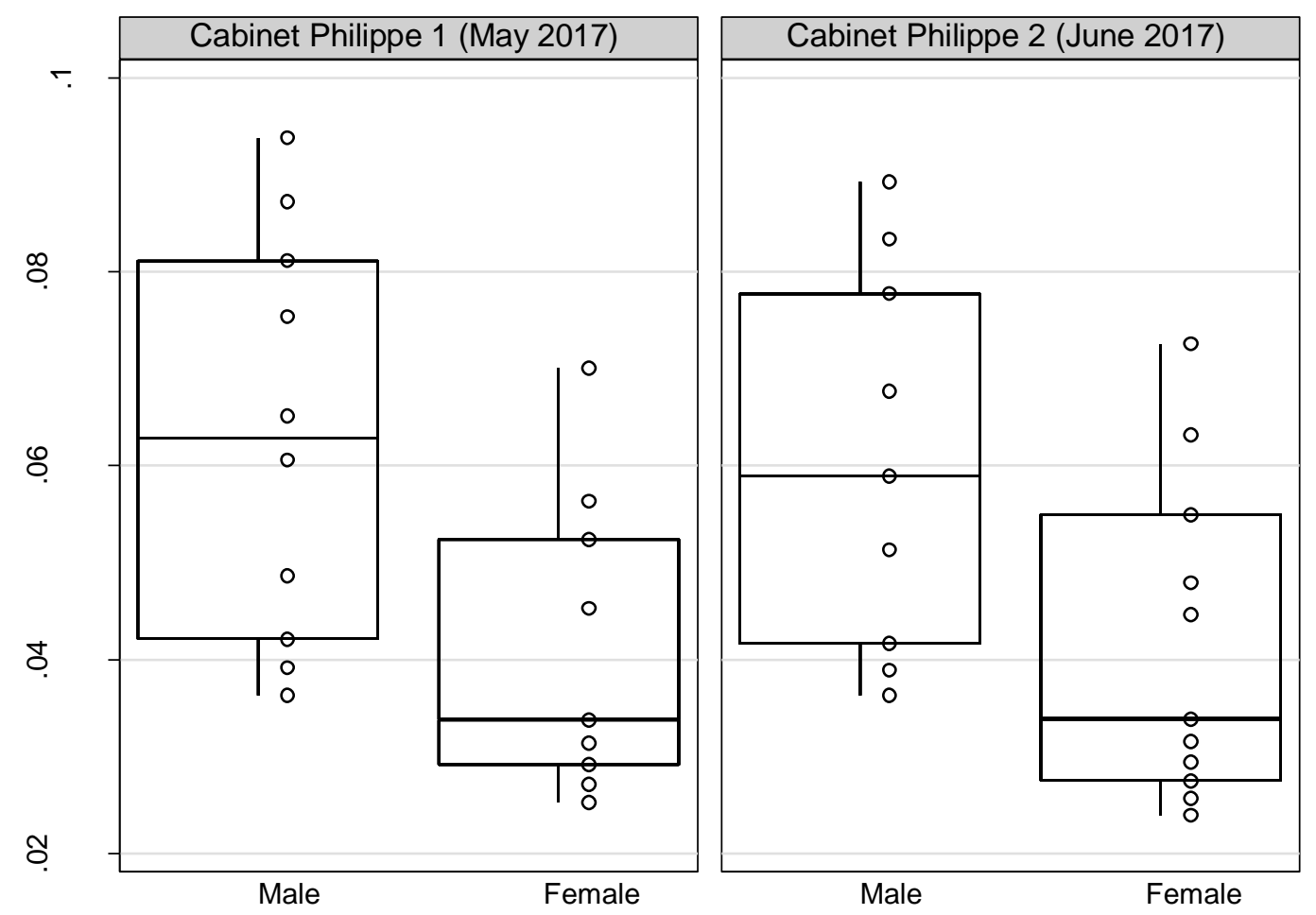

Note: State secretaries not included. 


\section{References}

Amorim Neto, Octavio, and Gary W. Cox (1997). "Electoral Institutions , Cleavage Structures, and the Number of Parties", American Journal of Political Science, 41:1, 149-74.

Ansolabehere, Stephen, James M. Snyder, Aaron B. Strauss, and Michael M. Ting (2005). "Voting Weights and Formateur Advantages", American Journal of Political Science, $49: 3,550-63$.

Bach, Laurent (2012). Faut-il abolir le cumul des mandats? Paris: Rue d'Ulm / Presses de l’École Normale Supérieure.

Baron, David P., and John A. Ferejohn (1989). "Bargaining in Legislatures", American Political Science Review, 83:4, 1181-206.

Bedock, Camille (2017). The government of Edouard Philippe: talkin' about a revolution? [online], WHO governs in Europe and beyond. Available from:

https://whogoverns.eu/the-government-of-edouard-philippe-talkin-about-a-revolution/.

Bucur, Cristina (2013). Who fires ministers? A principal-agent approach to ministerial deselection. PhD Thesis. Dublin City University.

Bucur, Cristina (2016). "Cabinet payoffs in coalition governments: A time-varying measure of portfolio importance", Party Politics.

Carcassonne, Guy (2011). La Constitution. 10th ed. Paris: Seuil.

Chapuis, Nicolas (2017). "Une telle pluralité n'avait jamais été observée dans un gouvernement", Le Monde, 18 May.

Cole, Alistair (2012). "The Fast Presidency? Nicolas Sarkozy and the political institutions of the Fifth Republic", Contemporary French and Francophone Studies, 16:3, 311-21.

Coquaz, Vincent (2017). "Un «gouvernement resserré» (mais pas trop)", Libération, 17 May.

Costa, Olivier, and Eric Kerrouche (2009). "MPs under the Fifth Republic: Professionalisation within a Weak Institution", West European Politics, 32:2, 327-44.

Courtois, Gérard (2017). "Emmanuel Macron a constitué un gouvernement à son image", Le Monde, 22 Jun, pp. 1-3.

Couvelaire, Louise (2017). "Les nouveaux députés LRM issus de l'immigration discrets sur leurs origines", Le Monde, 21 Jun.

Delrue, Maxime, and Maxime Vaudano (2017). "Nouveau gouvernement: quelle différence entre un ministre et un secrétaire d'Etat?", LeMonde, 17 May.

Dewoghélaëre, Julien, Raul Magni Berton, and Julien Navarro (2006). "'Cumul des Mandats' 
in Contemporary French Politics. An Empirical Study of the XIIe Legislature of the Assemblee Nationale", French Politics, 4:3, 312-32.

Dolez, Bernard (2015). "Le Parti socialiste, les primaires et la (dé)présidentialisation du régime", Pouvoirs, revue française d'études constitutionnelles et politiques, 154:3, 6779.

Druckman, James N., and Andrew Roberts (2008). "Measuring portfolio salience in Eastern European parliamentary democracies", European Journal of Political Research, 47:1, $101-34$.

Druckman, James N., and Paul V. Warwick (2005). "The missing piece: Measuring portfolio salience in Western European parliamentary democracies", European Journal of Political Research, 44, 17-42.

Duhamel, Olivier (2011). Droit constitutionnel et institutions politiques. Second Ed. Paris: Seuil.

Dupont, Gaëlle (2017). "Droits des femmes: la nouvelle secrétaire d'Etat, Marlène Schiappa, attendue au tournant", Le Monde, 17 May.

Elgie, Robert (2013). "The French Presidency", in Alistair Cole, Sophie Meunier, and Vincent Tiberj (eds.), Developments in French Politics 5. Basingstoke: Palgrave Macmillan, 1934.

Elgie, Robert, Cristina Bucur, Bernard Dolez, and Annie Laurent (2014). "Proximity, Candidates, and Presidential Power: How Directly Elected Presidents Shape the Legislative Party System.", Political Research Quarterly, 67:3, 467-77.

François, Abel (2006). "Testing the 'Baobab Tree' Hypothesis: The Cumul des Mandats as a Way of Obtaining More Political Resources and Limiting Electoral Competition", French Politics, 4:3, 269-91.

Gaffney, John (2010). Political Leadership in France Beyond Stereotypes: From Charles de Gaulle to Nicolas Sarkozy. Houndmills: Palgrave Macmillan.

Gamson, William A. (1961). "A Theory of Coalition Formation", American Sociological Review, 26:3, 373-82.

Garrett, Amanda (2017). "An easy concession or meaningful representation? Minority women in French politics", French Politics, 15:2, 166-86.

Gaxie, Daniel (1986). "Immuables et changeants: les ministres de la Ve république", Pouvoirs, revue française d'études constitutionnelles et politiques, 36, 61-79.

Golder, Matt (2006). "Presidential Coattails and Legislative Fragmentation", American Journal of Political Science, 50:1, 34-48. 
Kam, Christopher, and Indridi H. Indridason (2009). "Cabinet dynamics and ministerial careers in the French Fifth Republic", in Keith Dowding and Patrick Dumont (eds.), The Selection of Ministers in Europe: Hiring and Firing. London: Routledge, 41-57.

Knapp, Andrew, and Vincent Wright (2006). The Government and Politics of France. 5th ed. London: Routledge.

Little, Conor (2012). Brought in from the cold or marginalised? Women in the Hollande/Ayrault cabinet [online]. Available from: https://conorlittle.wordpress.com/2012/05/17/brought-in-from-the-cold-or-marginalisedwomen-in-the-hollandeayrault-cabinet/.

Mény, Yves (2008). "Des mœurs irréformables?", Pouvoirs, revue française d'études constitutionnelles et politiques, 126, 37-46.

Le Monde (2017). "Age, études, sexe: comment les profils des ministres ont évolué depuis 1981", Le Monde, $6 \mathrm{Jul}$.

Motet, Laura (2017). "Diversité ethnique : le gouvernement Philippe ne fait pas mieux que les précédents", Le Monde, 24 May.

Murray, Rainbow (2009). "Was 2007 a Landmark or a Let-Down for Women'S Political Representation in France?", Representation, 45:1, 29-38.

Murray, Rainbow (2013). "Towards parity democracy? Gender in the 2012 French legislative elections", Parliamentary Affairs, 66:1, 197-212.

Murray, Rainbow (2016). "The Political Representation of Ethnic Minority Women in France", Parliamentary Affairs, 69:3, 586-602.

Pommiers, Eléa (2017). "Les ministres de la société civile sont-ils vraiment étrangers à la politique?", Le Monde, 19 May.

Portelli, Hugues (1997). "Les Premiers ministres: essai de typologie", Pouvoirs, revue française d'études constitutionnelles et politiques, 83, 21-30.

Royer, Solenn de, and Cédric Pietralunga (2017). "Macron nomme un gouvernement d'experts", Le Monde, 22 Jun, pp. 21-3.

Shugart, Matthew Søberg (1995). "The Electoral Cycle and Institutional Sources of Divided Presidential Government", The Americal Political Science Review, 89:2, 327-43.

Sineau, Mariette (2011). Femmes et pouvoirs sous la Ve République : de l'exclusion à l'entrée dans la course présidentielle. Paris: Presses de Sciences Po.

Warwick, Paul V., and James N. Druckman (2006). "The portfolio allocation paradox: An investigation into the nature of a very strong but puzzling relationship", European Journal of Political Research, 45:4, 635-65. 